\title{
Response of Fine Rice (Oryza sativa L.) to various Planting Dates and Seedling Densities under Arid Environment of Dera Ismail Khan
}

\author{
M. Azam, Iqtidar Hussaian*, Ghazanfar ullah, A.A. Khakwani, M.S. Baloch, K. Waseem, M. Amjed \\ Nadeem and M.K. Javaid
}

Department of Agronomy, Gomal University, Pakistan.

\begin{abstract}
Climate change has emerged as the most prominent global environmental issues and there is a need to evaluate its impact on agriculture. It is need of the hour to determine suitable transplanting time for rice in this changing climate scenario to have better yield. The experiment was conducted to study the response of transplanting dates and seedlings densities on fine rice variety "Super Basmati" at Agronomic Research Farm, Faculty of Agriculture, Gomal University, Dera Ismail Khan during 2017. The experiment was laid out in a Randomized complete block design with three replications, because of two factors and

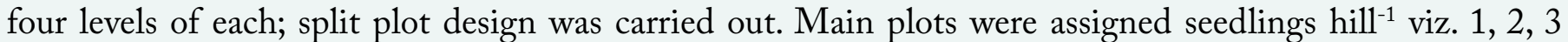
and 4 seedlings, while sub-plots were of four different transplanting dates i.e. $18^{\text {th }} \mathrm{July}, 25^{\text {th }} \mathrm{July}$, 1st August and $8^{\text {th }}$ August. Data was recorded on flag leaf area $\left(\mathrm{cm}^{2}\right)$, chlorophyll content $\left(\mu \mathrm{g} \mathrm{cm}^{-2}\right)$, plant height $(\mathrm{cm})$, number of fertile tillers hill ${ }^{-1}$, number of unfertile tillers hill ${ }^{-1}$, panicle length $(\mathrm{cm})$, spikelet fertility $(\%)$, number of grains panicle ${ }^{-1}, 1000$-grain weight $(\mathrm{g})$, biological yield $\left(\mathrm{kg} \mathrm{ha}^{-1}\right)$, grain yield $\left(\mathrm{kg} \mathrm{ha}^{-1}\right)$, benefit cost ratio (BCR) and Harvest index (\%). Seedling density showed significant differences for traits such as unfertile tiller hill ${ }^{-1}$, while transplanting dates also indicated significant differences for biological yield, grain yield, plant height, spikelet fertility (\%), 1000-grain yield and number of unfertile tiller per plant. Seedling densities and transplanting dates interaction also showed significant differences for various parameters under study. Data revealed that 3 seedlings hill $^{-1}$ transplanted on $18^{\text {th }}$ July gave maximum grain yield (4700 $\mathrm{kg} \mathrm{ha} \mathrm{h}^{-1}$ ) and benefit cost ratio (2.70). Therefore, fine rice variety "Super Basmati" is recommended for transplanting on $18^{\text {th }}$ July by using 3 seedling hill ${ }^{-1}$ under the environmental conditions of Dera Ismail khan.

Received | March 21, 2021; Accepted | August 23, 2021; Published | October 01, 2021

*Correspondence | Iqtidar Hussaian, Department of Agronomy, Gomal University, Pakistan; Email: iqtidarhussain453@yahoo.com

Citation | Azam, M., I. Hussaian, G. Ullah, A.A. Khakwani, M.S. Baloch, K. Waseem, M. Amjed Nadeem and M.K. Javaid. 2021. Response of fine rice (Oryza sativa L.) to various planting dates and seedling densities under arid environment of Dera Ismail Khan. Pakistan Journal of Agricultural Research, 34(4): 781-791.

DOI | https://dx.doi.org/10.17582/journal.pjar/2021/34.4.781.791

Keywords | Fine rice, Transplanting time, Benefit cost ratio, Environment, Seedling densities
\end{abstract}

\section{Introduction}

$\mathrm{O}$ $\mathrm{n}$ universal based, rice crop is planted on region of 153 million hectares among whole production of 672 million tons. China is the biggest grower of rice, the total production is 196 million tons and after that India is the 2 nd biggest rice producer in the world within 133 million tons, while Indonesia produced sixty four million tons, Bangladesh forty seven million tons, Vietnam thirty eight million tons \& Myanmar thirty two million tons. However, in $\mathrm{Pa}-$ kistan rice is grown on 2.3 million hectares area by means of total production of rice in Pakistan is 7.2 million tons (FAOSTAT, 2017). Pakistan is among from those countries which are producing and exporting very good quality fine rice. In our country rice 
is the second most important cereal after wheat, not only in view of local consumption but also in view of exports (Noreen et al., 2020). The productivity in terms of yield and value is governed by varieties and managing practices. Suitable planting of basmati rice is a key factor in influential grain yield and quality parameters. The region under aromatic rice cultivars are raising day by day through the opportunity of world market as well as domestic utilization (Singh et al., 2008). However, the yield of rice crop in Pakistan is quite low in comparison to developed world as well as ever growing population of the country; then is dire need to enhance rice yield abruptly. Among several factors; fertilizers, plant population, time of sowing and transplanting time can significantly increase the rice yield (Amin et al., 2004). Rice crop largely depends on moisture, temperature, solar radiations for its successful growth and development. Rice requires an ample amount of water and plants population for maximum grain yield production as compared to other cereals (Turin et al., 2021). The overcrowding of plants adversely effects equal distribution of edaphic factors, whereas their plants stand cannot fully utilize resources in the surroundings. Therefore, optimum plants stand is a key to achieve highest yield target. Shrirame et al. (2000) took significantly higher tillers per hill by transplanting two seedlings hill ${ }^{-1}$. Bhowmik et al. (2012) also endorsed the significance of seedlings hill ${ }^{-1}$ as it helped in capturing maximum nutrients, which improved photosynthetic and respiratory mechanism of plant and ultimate crop yield. Alam (2006) reported maximum production and total tillers by transplanting 2 seedlings hill ${ }^{-1}$. However, Obulamma et al. (2002) recommended two seedlings per hill to obtain maximum dry matter, leaf area index \& leaf area density in contrast to three seedlings per hill which provided highest net assimilation rate, crop growth rate and seed production. Knowing of best transplanting time of Basmati Rice is also an important step to obtain maximum yield. It is also reported that too late or too early time of transplanting can drastically influence rice yield which not only bring sterility in rice panicle but also share cause in reduction in fertile rice tiller in rice (Safdar et al., 2008).

Planting densities plays vital role in the yield of rice. Low, medium and high densities each have different correlation with yield parameters of rice. It is essential to find out the best plating densities corrected with high yield of rice to fulfill the requirement of rice worldwide (Mulcahy et al., 2013). Rice is grown in all continents of the world because it is extensive adaptability to diverse agro climatic conditions (Sharma et al., 2011).

\section{Materials and Methods}

An experiment was conducted at Faculty of Agriculture in 2017 cropping season under irrigation from June to November 2017. The site is located in the Gomal University in Dera Ismail Khan in the Khyber Pakhtunkhwa province of Pakistan. The altitude ranges from $165 \mathrm{~m}$ higher than sea level. It is located at $31^{\circ} 48^{\prime} 59.99^{\prime \prime} \mathrm{N}$ latitude and $70^{\circ} 54^{\prime} 59.99^{\prime \prime} \mathrm{E}$. An experiment was conducted to check the response of different levels of seedlings hill ${ }^{-1}$ viz., 1,2,3,4 were assigned as main plots, whereas, different transplanting dates i.e., $18^{\text {th }}$ of July, $25^{\text {th }}$ of July, $1^{\text {st }}$ August and $8^{\text {th }}$ of August were assigned as sub plots. It is warm and dried out in summer with temperate spells during the monsoon season (Baloch et al., 2006). The experiment was undertaken to study the response of transplanting dates and seedlings per hill on fine rice variety "Super Basmati". For this purpose, RCBD in splitplot planning was used with three replications. Different levels of seedlings hill ${ }^{-1}$ viz. $1,2,3 \& 4$ were assigned as main plots, whereas different transplanting dates i.e. $18^{\text {th }}$ July, $25^{\text {th }}$ July, $1^{\text {st }}$ August $\& 8^{\text {th }}$ August were assigned as sub-plots. The net plot size was 3 $\mathrm{m} \times 4 \mathrm{~m}\left(12 \mathrm{~m}^{2}\right)$. The distance between plants was maintained as $25 \mathrm{~cm}$. The recommended NPK dose of 120:60:60 kg ha ${ }^{-1}$ was used for fine rice, whereas sources of fertilizer were Urea, SSP and SOP. Half of the nitrogen was applied at 25 days after transplanting and remaining half was applied 45 days after transplanting, phosphorus and potassium was applied before transplanting. Zinc was also applied in the form of $\mathrm{ZnSo}_{4}$ (33\%) @ $12 \mathrm{~kg} \mathrm{ha} \mathrm{kg}^{-1}$ after 10 days of transplanting. The weeds in rice field were controlled by using weedicide Rifit (Pritilaclor 100\% $500 \mathrm{~g}(\mathrm{w} / \mathrm{v})$ @1000 ml ha ${ }^{-1}$, which was flooded within 24 hours of transplantation. Insects in rice crop was controlled by using pesticides Vertaco 0.6 GR (Thiomethokism $0.4 \%$ and Chlorintraniliprol 0.2\%) @ $10 \mathrm{~kg} \mathrm{ha}^{-1}$ at 25 and 60 days after transplantation. The detail of the treatments is mentioned in the following lines.

\section{Statistical analysis}

The collected data were analyzed statistically through analysis of variance technique (Steel et al., 1997). In addition, means of treatment were obtained by utilizing Duncan Multiple Range Test at 5\% level of probability through software package 'Statistics'. 
Results and Discussion

\section{Flag leaf area $\left(\mathrm{cm}^{2}\right)$}

The maximum flagleafarea $\left(26.50 \mathrm{~cm}^{2}\right)$ was recorded on earliest transplanting date 18-7-2017 while minimum flag leaf area $\left(23.00 \mathrm{~cm}^{2}\right)$ was found on transplanting date 8-8-2017. For planting densities the maximum flag leaf area $\left(26.97 \mathrm{~cm}^{2}\right)$ was noted on 3 seedlings per hill $^{-1}$. While smallest flag leaf area $\left(22.26 \mathrm{~cm}^{2}\right)$ was noted in treatment with 1 seedling per hill (Table 1 ).

\section{Chlorophyll content $\left(\mu \mathrm{g} \mathrm{cm}^{-2}\right)$}

An important indicator of physiological growth and development is chlorophyll content $\left(\mu \mathrm{g} \mathrm{cm}^{-2}\right)$. Chlorophyll absorbed radiant energy and converts it to chemical energy by process of photosynthesis. Chlorophyll content was measured with the help of chlorophyll spad photometer (Minolta meter). Zhaofen et al. (2016). The highest mean of transplantation date for chlorophyll content $\left(41.98 \mu \mathrm{g} \mathrm{cm}^{-2}\right)$ was recorded on $1^{\text {st }}$ transplantation date (18-7-2017). While lowest value $\left(38.16 \mu \mathrm{g} \mathrm{cm}^{-2}\right)$ for chlorophyll content was recorded for $4^{\text {th }}$ and last trans-plantation date held on 8-8-2017. The highest mean of plant density for chlorophyll content $\left(44.20 \mu \mathrm{g} \mathrm{cm}^{-2}\right)$ was recorded for 3 plants per hill, whereas lowest mean for chlorophyll content $\left(35.34 \mu \mathrm{g} \mathrm{cm}^{-2}\right)$ was recorded for 1 plant per hill. As far as interaction is concerned number the highest value of chlorophyll content $\left(46.00 \mu \mathrm{g} \mathrm{cm}^{-2}\right)$ was recorded for 3 plant hill ${ }^{-1}$ under $1^{\text {st }}$ transplantation date ( $\left.18^{\text {th }} \mathrm{July}\right)$, while, lowest value of chlorophyll content $\left(33.70 \mu \mathrm{g} \mathrm{cm}^{-2}\right)$ was obtained in 1 seedlings hill-1 in $4^{\text {th }}$ transplantation date $8^{\text {th }}$ August, 2017 (Table 1).

\section{Plant height $(\mathrm{cm})$}

The all-out plant height $(138.50 \mathrm{~cm})$ was recorded for first transplantation date 18-7-2017, while least plant height $(125.17 \mathrm{~cm})$ was recorded for $4^{\text {th }}$ and last transplantation date viz., 8-8-2017. As far as the interaction is concerned, the all-out plant height $(144.33 \mathrm{~cm})$ was recorded for 3 plant hill ${ }^{-1}$ under first transplantation date ( $18^{\text {th }}$ July), whereas least plant height $(123.33 \mathrm{~cm})$ was recorded for 1 seedling hill ${ }^{-1}$ under $4^{\text {th }}$ transplantation date 8th August (Table 1).

\section{Number of fertile tillers bill ${ }^{-1}$}

The determined number of fertile tillers $/$ hill $^{-1}$ (39.41) were noted for first transplantation date planted on 18-7-2017, whereas lowest (21.66) number of fertile tillers $/$ hill $^{-1}$ were noted for $4^{\text {th }}$ transplantation date held on 8-8-2-17. Determined number of fertile till- ers hill ${ }^{-1}$ (37.58) were noted for 3 plant hill ${ }^{-1}$, whilst smallest number of fertile tillers hill ${ }^{-1}(19.50)$ were noted for 1 plant per hill. As far as interaction is concerned, the determined number of fertile tillers hill- ${ }^{-1}$ (49.33) were noted for 3 plant hill ${ }^{-1}$ under $1^{\text {st }}$ transplantation date (18 $18^{\text {th }}$ July), while, smallest number of fertile tillers hill-1 $(12.00)$ were noted in 1 seedlings hill ${ }^{-1}$ under $4^{\text {th }}$ transplantation date 8-8-2017 (Table 2).

\section{Number of unfertile tillers bill ${ }^{-1}$}

Maximum number of unfertile tillers hill ${ }^{-1}(11.66)$ were noted for $4^{\text {th }}$ transplantation date planted on $8^{\text {th }}$ August 2017, whereas minimum unfertile tillers hill-1 (6.33) were noted for $1^{\text {st }}$ transplantation held on $18^{\text {th }}$ July, 2017. As far as planting density is concerned, the maximum unfertile tillers hill ${ }^{-1}(10.58)$ were recorded in plot transplanted with 3 seedling hill ${ }^{-1}$, whereas, minimum unfertile tillers hill ${ }^{-1}$ (8.08) were measured in 1 seedling hill ${ }^{-1}$ transplanted rice (Table 2).

\section{Panicle length $(\mathrm{cm})$}

The highest value $(31.66 \mathrm{~cm})$ for panicle length was noted for 1st transplantation date planted on 18-72017, whereas lowermost $(19.50 \mathrm{~cm})$ panicle length was measured for four and last transplantation held on 8-8-217. Extreme mean value $(26.50 \mathrm{~cm})$ for panicle length was noted for single plant hill-1 ${ }^{-1}$ although lowest mean $(22.50 \mathrm{~cm})$ for panicle length was measured for four plant hill-1. The interaction of number of seedling hill-1 ${ }^{-1}$ over transplantation date highest value $(36.00 \mathrm{~cm})$ of panicle length was noted for single plant hill-1; however shortest length $(18.00 \mathrm{~cm})$ of panicle was noted for four seedlings hill-1 (Table 2).

\section{Spikelet fertility (\%)}

The maximum mean (90.11\%) of transplantation date for spikelet fertility (\%) was calculated for last transplantation date viz., 08-8-2017, whereas minimum $(80.26 \%)$ values for spikelet fertility was recorded for $1^{\text {st }}$ transplantation held on $18^{\text {th }}$ July, 2017 (Table 3).

\section{Number of grains panicle-1}

The uppermost number of grains panicle ${ }^{-1}$ (107.67) was calculated for $1^{\text {st }}$ transplantation date (18 July, 2017), however lowest values (83.00) for grain panicle $^{-1}$ was noted for last transplantation held on 8-82017. As far as seedling density is concerned, the uppermost value (95.33) for number of grain panicle ${ }^{-1}$ was calculated for three plants hill ${ }^{-1}$, while smallest value (92.33) grain panicle ${ }^{-1}$ was noted for single plant hill-1 ${ }^{-1}$ Regarding interaction between number of 
seedling hill ${ }^{-1}$ and trans-planting dates for number of grains per panicle. The uppermost number of grains per panicle (109.33) were calculated for three plant hill ${ }^{-1}$ under $1^{\text {st }}$ transplanting date (18-7-2017), while lowest value (82.00) for number of grains panicle ${ }^{-1}$ was noted for single seedling hill ${ }^{-1}$ under $4^{\text {th }}$ transplantation date 8-8-2017 (Table 3).

\section{0-grain weight (g)}

Maximum 1000-grains weight (25.83 g) were reported in $1^{\text {st }}$ transplantation date (18 July, 2017), while, lowest (20.83 g) weight grains were obtained in treatments trans-planted on last transplantation held on 8-8-2017 (Table 3).

\section{Biological yield $\left(\mathrm{kg} \mathrm{ha}^{-1}\right)$}

The supreme biological yield $\left(11532 \mathrm{~kg} \mathrm{ha}^{-1}\right)$ was noted for $1^{\text {st }}$ transplantation date (18-7-2017), whereas lowest biological yield (10154 $\left.\mathrm{kg} \mathrm{ha}^{-1}\right)$ was noted for last transplantation (8-8-2017). Maximum biological yield (11244 kg ha $\mathrm{kg}^{-1}$ ) was calculated for four plants hill $^{-1}$, however the least values $\left(10134 \mathrm{~kg} \mathrm{ha}^{-1}\right)$ for biological yield was noted for single plant hill-1. As far as the interaction among numbers of seedling hill-1 over transplantation date for biological yield ( $\mathrm{kg} \mathrm{ha}$ $\left.{ }^{1}\right)$, is concaved the height value $\left(11755 \mathrm{~kg} \mathrm{ha}^{-1}\right)$ for biological yield was noted for three plant hill ${ }^{-1}$ under $1^{\text {st }}$ transplantation date (18-7-2017), whereas, lowest biological yield (9200 kg ha-1) was calculated for single seedlings hill ${ }^{-1}$ under fourth transplantation date at 8-8-2017 (Table 4).

\section{Grain yield $\left(\mathrm{kg} \mathrm{ha}^{-1}\right)$}

Maximum mean value (4161 kg ha-1) for grain yield was noted for $1^{\text {st }}$ transplantation date (18 July, 2017), whereas smallest value ( $3331 \mathrm{~kg} \mathrm{ha}^{-1}$ ) for grain yield was calculated for last transplantation ( $8^{\text {th }}$ August). The maximum mean value (4266 $\mathrm{kg} \mathrm{ha}^{-1}$ ) for grain yield was calculated for three plants per hill however lowest values $\left(2977 \mathrm{~kg} \mathrm{ha}^{-1}\right)$ for grain yield were calculated for single plant per hill. The interaction between of number of seedling per hill over transplanting dates for grain yield showed that maximum of grain yield $\left(4700 \mathrm{~kg} \mathrm{ha}^{-1}\right)$ was noted for three plant hill ${ }^{-1}$ under $1^{\text {st }}$ transplanting date on 18-7-2017, although, minimum grain yield $\left(2540 \mathrm{~kg} \mathrm{ha}^{-1}\right)$ was noted for single seedling per hill under fourth transplantation date i.e., $8^{\text {th }}$ of August (Table 4).

Harvest index (\%)

The highest mean value (36.11\%) for harvest index was recorded in $1^{\text {st }}$ transplantation date planted on $18^{\text {th }}$ July, however smallest value $(32.73 \%)$ harvest index was calculated for last transplantation on $8^{\text {th }} \mathrm{Au}-$ gust 2017. Maximum value of plant density for harvest index (38.48\%) was noted for three plants hill ${ }^{-1}$, whereas a smallest value (29.48\%) for harvest index was calculated for single plant per hill. The interaction among number of seedling per hill and transplanting date for harvest index showed that maximum value (39.99\%) was calculated for 3 plant per hill under first transplantation date of 18-7-2017, whereas lowermost $(27.74 \%)$ harvest index was noted for 1 seedlings per hill under fourth transplantation date held on 8-8-2017 (Table 4).

\section{Benefit cost ratio}

In current work, the highest net return of Rs.107449/ ha and benefit cost ratio (2.70) was found from rice transplanted on 18th of July, 2017 along with three seedlings hill ${ }^{-1}$. Whilst, lower most benefit cost ratio (1.51) \& net amount of Rs.31149/- was obtained from rice transplanted on last date 8-8-2017 in arrangement with 1 plant seedling (Table 5).

Analysis of variance showed significant differences as affected by number of seedling hill $^{-1}$, transplantation date, while number of seedling hill ${ }^{-1}$ and transplantation interaction indicated non-significant differences in Table 1 regarding flag leaf area. These results are supported by Ahmad et al. (2005) who findings showed significant outcome in flag leaf by the use of seedling densities and transplantation time. The increase in flag leaf area might be due to optimum density per unit area for rice (Baloch et al., 2012). Nangyal et al. (2016) also reported an increased leaf area by increasing density of plants. The mean value of number of seedling hill ${ }^{-1}$ over transplantation date ranged from 20.26 to $26.97 \mathrm{~cm} 2$ for flag leaf area also found significant difference of plant density and irrigation regimes for flag leaf area. The interaction between transplantation time and planting density remained non-significant. As there was no variation in interaction for plant density and transplantation date. The data regarding chlorophyll content $(\mu \mathrm{g} \mathrm{cm}-2)$ as presented in Table 1 clearly depicted a significant behavior for numbers of seedling hill ${ }^{-1}$, transplanting date and their interaction, Chauhan (2012), Khalifa (2009) also found significant differences of various transplantation dates for chlorophyll content and recommended early date of transplantation for more yield and chlorophyll content. 
Table 1: Response of Fine Rice (Oryza sativa L.) to various Planting Dates and Seedling Densities on Physiological traits.

\begin{tabular}{|c|c|c|c|c|c|c|}
\hline \multirow[t]{7}{*}{ Flag leaf area $\left(\mathrm{cm}^{2}\right)$} & \multirow[t]{2}{*}{ Transplanting Dates } & \multicolumn{4}{|c|}{ Seedling Densities } & \multirow[t]{2}{*}{ Mean } \\
\hline & & $\mathrm{P}_{1}$ & $\mathrm{P}_{2}$ & $\mathrm{P}_{3}$ & $\mathrm{P}_{4}$ & \\
\hline & $\mathrm{D}_{1}(18-07-2017)$ & $24.52^{\mathrm{NS}}$ & 25.13 & 29.08 & 27.29 & $26.50 \mathrm{a}$ \\
\hline & $\mathrm{D}_{2}(25-07-2017)$ & 22.29 & 24.13 & 27.41 & 25.74 & $24.89 \mathrm{~b}$ \\
\hline & $\mathrm{D}_{3}(01-08-2017)$ & 21.53 & 23.38 & 26.22 & 24.22 & $23.83 \mathrm{c}$ \\
\hline & $\mathrm{D}_{4}(08-08-2017)$ & 20.70 & 22.48 & 25.17 & 23.670 & $23.00 \mathrm{~d}$ \\
\hline & Mean & $22.26 \mathrm{~d}$ & $23.78 \mathrm{c}$ & $26.97 \mathrm{a}$ & $25.23 \mathrm{~b}$ & \\
\hline \multirow{6}{*}{$\begin{array}{l}\text { Chlorophyll con- } \\
\text { tent }\left(\mu \mathrm{g} \mathrm{cm}^{-2}\right)\end{array}$} & & & & & & \\
\hline & $\mathrm{D}_{1}(18-07-2017)$ & $36.83 \mathrm{j}$ & $40.96 \mathrm{fg}$ & $46.00 \mathrm{a}$ & $44.13 \mathrm{bc}$ & $41.98 \mathrm{a}$ \\
\hline & $\mathrm{D}_{2}(25-07-2017)$ & $35.96 \mathrm{k}$ & $39.76 \mathrm{~h}$ & $44.93 \mathrm{~b}$ & $42.73 \mathrm{de}$ & $40.85 \mathrm{~b}$ \\
\hline & $\mathrm{D}_{3}(01-08-2017)$ & $34.86 \mathrm{k}$ & $38.66 \mathrm{i}$ & $43.66 \mathrm{~cd}$ & $41.43 \mathrm{f}$ & $39.65 \mathrm{c}$ \\
\hline & $\mathrm{D}_{4}(08-08-2017)$ & 33.701 & $36.13 \mathrm{jk}$ & 42.23 ef & $40.60 \mathrm{gh}$ & $38.16 \mathrm{~d}$ \\
\hline & Mean & $35.34 \mathrm{~d}$ & $38.88 \mathrm{c}$ & $44.20 \mathrm{a}$ & $42.22 \mathrm{~b}$ & \\
\hline \multicolumn{7}{|l|}{ Plant height (cm) } \\
\hline & $\mathrm{D}_{1}(18-07-2017)$ & $134.67 \mathrm{bc}$ & $135.67 \mathrm{bc}$ & $144.33 a$ & $139.33 \mathrm{~b}$ & $138.50 \mathrm{a}$ \\
\hline & $\mathrm{D}_{2}(25-07-2017)$ & 131.33 cde & 132.33 cde & $138.33 \mathrm{~b}$ & $135.00 \mathrm{bc}$ & $134.25 \mathrm{~b}$ \\
\hline & $\mathrm{D}_{3}(01-08-2017)$ & $128.33 \mathrm{~d}-\mathrm{g}$ & $128.00 \mathrm{efg}$ & $133.00 \mathrm{bcd}$ & $131.00 \mathrm{c}-\mathrm{f}$ & $130.08 \mathrm{c}$ \\
\hline & $\mathrm{D}_{4}(08-08-2017)$ & $123.33 \mathrm{~g}$ & $124.00 \mathrm{~g}$ & $127.67 \mathrm{efg}$ & $125.67 \mathrm{fg}$ & $125.17 \mathrm{~d}$ \\
\hline & Mean & $129.42^{\mathrm{NS}}$ & 130.00 & 135.83 & 132.75 & \\
\hline
\end{tabular}

Our findings are similar to Turin et al. (2021). They explained that chlorophyll content \& other grain yield contributing parameters are seriously affected by planting densities $\&$ a-biotic stress. These results could well be due to optimum transplantation time (mid of July) for best chlorophyll contest. A significant difference was noted for plant density regarding chlorophyll content (Chutia and Borah, 2012). Statistical analysis indicated significant differences for transplantation dates and their interaction while number of seedling hill ${ }^{-1}$ indicated non-significant difference for plant height $(\mathrm{cm})$ in Table 1 . The increase in plant height might be due to optimum date of transplanting which increased over all crop growth duration and ultimate height of plant. The results plant densities on plant height remained non-significant (Wang et al., 2012). Vijayalaxmi (2016) also reported significant difference in plant height of rice as affected by various dates for transplantation. This may be due to extra vigor and root development because of extra leaf area which stimulates increased cell separation causing additional stem elongation (Asad et al., 2015).

Analysis of variance indicated significant as affected by number of seedling hill-1 and transplantation date the number of seedling hill ${ }^{-1}$ and their interaction on fertile tillers hill-1 (Table 2).

Biswas et al. (2015) also reported significant differences of different transplantation date for number of fertile tillers hill ${ }^{-1}$. This might due to the quick establishment of seedlings after transplantation because during uprooting they suffered minimal root injury along with minute root shock as well as death rate. These results are similar with the findings of Imran et al. (2015) who explained that earlier trans-plantation facilitated fertile tillers per plant. Baloch et al. (2006) found also significant differences of plant density for number of fertile tillers hill ${ }^{-1}$. The data about unfertile tillers hill ${ }^{-1}$ indicated that seedling hill ${ }^{-1}$ and transplanting date showed significant results while their interaction was found non-significant in spikelet fertility Table 3. Our research got support from the previous findings of Alam et al. (2012), Turin et al. (2021) who also found significant differences of transplantation date for unfertile tillers hill $^{-1}$. The number of fertile tillers and unfertile tillers hill ${ }^{-1}$ is greatly affected quantitatively by the number of seedlings per hill. Optimum number of seedlings per hill may facilitate the rice plant to grow properly both in its aerial and underground parts. Excess number of seedlings per hill may produce higher number of tillers per hill. On the other hand, the lesser number of seedlings per hill may cause insufficient tiller number (Bhowmik et al., 2012; Islam et al., 2014). 
Table 2: Response of Fine Rice (Oryza sativa L.) to various Planting Dates and Seedling Densities on Tillering and panicle length $(\mathrm{cm})$.

\begin{tabular}{|c|c|c|c|c|c|c|}
\hline \multirow{7}{*}{$\begin{array}{l}\text { Fertile tillers } \\
\text { hill }^{-1}\end{array}$} & \multirow[t]{2}{*}{ Transplanting Dates } & \multicolumn{4}{|c|}{ Seedling Densities } & \multirow[t]{2}{*}{ Mean } \\
\hline & & $P_{1}$ & $\mathrm{P}_{2}$ & $\mathrm{P}_{3}$ & $\mathrm{P}_{4}$ & \\
\hline & $\mathrm{D}_{1}(18-07-2017)$ & $28.00 \mathrm{~g}$ & $38.00 \mathrm{c}$ & $49.33 \mathrm{a}$ & $42.33 \mathrm{~b}$ & $39.41 \mathrm{a}$ \\
\hline & $\mathrm{D}_{2}(25-07-2017)$ & $21.33 \mathrm{ij}$ & $29.00 \mathrm{fg}$ & $39.00 \mathrm{bc}$ & $37.00 \mathrm{~cd}$ & $31.58 \mathrm{~b}$ \\
\hline & $\mathrm{D}_{3}(01-08-2017)$ & $16.66 \mathrm{k}$ & $24.00 \mathrm{hi}$ & $34.00 \mathrm{de}$ & 32.00 ef & $26.66 \mathrm{c}$ \\
\hline & $\mathrm{D}_{4}(08-08-2017)$ & 12.001 & $20.00 \mathrm{jk}$ & $28.00 \mathrm{~g}$ & $26.66 \mathrm{gh}$ & $21.66 \mathrm{~d}$ \\
\hline & Mean & 19.50 & $27.75 \mathrm{~b}$ & $37.58 \mathrm{a}$ & $34.50 \mathrm{a}$ & \\
\hline \multirow{6}{*}{$\begin{array}{l}\text { Unfertile } \\
\text { tillers hill }^{-1}\end{array}$} & & & & & & \\
\hline & $\mathrm{D}_{1}(18-07-2017)$ & $5.00^{\mathrm{NS}}$ & 7.00 & 7.33 & 6.00 & $6.33 \mathrm{~d}$ \\
\hline & $\mathrm{D}_{2}(25-07-2017)$ & 7.00 & 9.00 & 10.00 & 8.00 & $8.50 \mathrm{c}$ \\
\hline & $\mathrm{D}_{3}(01-08-2017)$ & 9.33 & 11.00 & 12.00 & 10.00 & $10.58 \mathrm{~b}$ \\
\hline & $\mathrm{D}_{4}(08-08-2017)$ & 11.00 & 11.66 & 13.00 & 11.00 & $11.66 \mathrm{a}$ \\
\hline & Mean & $8.08 \mathrm{c}$ & $9.66 \mathrm{ab}$ & $10.58 \mathrm{a}$ & $8.75 \mathrm{bc}$ & \\
\hline \multirow{6}{*}{$\begin{array}{l}\text { Panicle length } \\
\text { (cm) }\end{array}$} & & & & & & \\
\hline & $\mathrm{D}_{1}(18-07-2017)$ & $36.00 \mathrm{a}$ & $31.00 \mathrm{~b}$ & $30.66 \mathrm{bc}$ & $29.00 \mathrm{c}$ & $31.66 \mathrm{a}$ \\
\hline & $\mathrm{D}_{2}(25-07-2017)$ & $26.33 \mathrm{~d}$ & $25.00 \mathrm{de}$ & 24.00 ef & $23.00 \mathrm{fgh}$ & $24.58 \mathrm{~b}$ \\
\hline & $\mathrm{D}_{3}(01-08-2017)$ & $23.33 \mathrm{efg}$ & 22.00 ghi & $21.33 \mathrm{hij}$ & $20.00 \mathrm{jk}$ & $21.66 \mathrm{c}$ \\
\hline & $\mathrm{D}_{4}(08-08-2017)$ & $20.33 \mathrm{ijk}$ & $19.00 \mathrm{kl}$ & $20.66 \mathrm{ijk}$ & 18.001 & $19.50 \mathrm{~d}$ \\
\hline & Mean & $26.50 \mathrm{a}$ & $24.25 \mathrm{~b}$ & $24.16 \mathrm{~b}$ & $22.50 \mathrm{c}$ & \\
\hline
\end{tabular}

Similar results were quoted by Lin et al. (2009) stating significant differences amongst different plant densities for unfertile tillers hill $^{-1}$ in rice. The interaction between transplantation time and planting density remained non- significant. As there was no variation in interaction for plant density and transplantation date. The experiment indicated that seedling hill ${ }^{-1}$, transplanting date and interaction showed significant results about panicle length $(\mathrm{cm})$ in Table 2. Presented significant results by sowing rice on different dates. Similarly, Gill et al. (2009) reported that basmati cultivars sown in July had significant positive effect on their yield. Similar result were quoted by Biswas et al. (2015) obtained highest panicle length from 4 seedlings per hill. As far as the interaction between both of the treatments is concerned, significant behavior was found for panicle of rice.

The data indicated that transplanting date showed significant results while seedling hill ${ }^{-1}$ and their interaction was found non-significant Table 3. Similar results were quoted by Hasamuzzaman (2009) who also reported significant difference amongst different transplanting date for rice spikelet fertility \%. Similarly, the interaction between number of seedlings and transplanting dates also gave non- significant results in affecting spikelet fertility of rice. Seedling hill 1 and transplanting date showed significant results on Table 3. Faruk et al. (2009) also found significant differences of various transplantation dates for number of grains panicle ${ }^{-1}$. This might be due to suitable temperature and effective solar radiations received by the crop during its life cycle. Bozorgi et al. (2011) and Kostylev et al. (2016) confirmed that by using various transplanting dates, there was significant positive impact on number of grains per spike. Bhowmik et al. (2012) observed significant differences of rice planting density for number of grain pancle ${ }^{-1}$. Such variably in filled grains per panicle is estimated as number of filled grains per panicle is dependent on several factors, for example genotypes, cultural methods applied, top soil and growth environment of the rice crop (Baloch et al., 2006). During this study, cultural methods such as different planting time acceptable the crop to complete its whole life cycle in a large range of environment condition which might have influence on number of filled grains per panicle of the cultivar over the planting time. The interaction among number of seedling hill ${ }^{-1}$ and transplantation date remained non-significant. 1000-grain is an essential yield factor which determines final yield. Statistical analysis indicated significant differences for transplantation dates while non-significant difference for number of seedling hill-1 and their interaction in Table 3. The probable reason for minimal 1000 grain weight $(\mathrm{g})$ is shortening of grain filling duration 
Table 3: Response of Fine Rice (Oryza sativa L.) to various Planting Dates and Seedling Densities on yield components.

Spikelet fertility Transplanting Dates (\%)

$$
\begin{aligned}
& \mathrm{D}_{1}(18-07-2017) \\
& \mathrm{D}_{2}(25-07-2017) \\
& \mathrm{D}_{3}(01-08-2017) \\
& \mathrm{D}_{4}(08-08-2017) \\
& \text { Mean }
\end{aligned}
$$

Grain panicle $^{-1}$

$$
\begin{aligned}
& \mathrm{D}_{1}(18-07-2017) \\
& \mathrm{D}_{2}(25-07-2017) \\
& \mathrm{D}_{3}(01-08-2017) \\
& \mathrm{D}_{4}(08-08-2017) \\
& \text { Mean }
\end{aligned}
$$

1000 grain weight

(g)

$$
\begin{aligned}
& \mathrm{D}_{1}(18-07-2017) \\
& \mathrm{D}_{2}(25-07-2017) \\
& \mathrm{D}_{3}(01-08-2017) \\
& \mathrm{D}_{4}(08-08-2017) \\
& \text { Mean }
\end{aligned}
$$

Seedling Densities
$\begin{array}{ll}\mathbf{P}_{1} & \mathbf{P}_{2} \\ 82.75^{\mathrm{NS}} & 82.83 \\ 86.41 & 85.60 \\ 89.44 & 87.01 \\ 92.94 & 91.34 \\ 87.88^{\mathrm{NS}} & 86.70\end{array}$

105.67

96.00

85.67

82.00

$92.33 \mathrm{~b}$

$\begin{array}{ll}28.00 \text { NS } & 26.00 \\ 25.66 & 24.00 \\ 23.33 & 22.33 \\ 22.00 & 21.00 \\ 24.75 \text { NS } & 23.33\end{array}$

109.00
99.67
87.33
83.67
$95.00 \mathrm{a}$

26.00
24.00
22.33
21.00
23.33

$\begin{array}{lll} & & \text { Mean } \\ \mathbf{P}_{3} & \mathbf{P}_{4} & \\ 80.54 & 75.13 & 80.31 \mathrm{~b} \\ 83.98 & 81.62 & 84.40 \mathrm{ab} \\ 87.07 & 84.62 & 87.03 \mathrm{a} \\ 90.47 & 87.32 & 90.52 \mathrm{a} \\ 85.52 & 82.17 & \end{array}$

109.33

100.00

106.33

$107.67 \mathrm{a}$

97.33

$98.25 \mathrm{~b}$

96.00

86.67

$86.92 \mathrm{c}$

84.00

82.33

$83.00 \mathrm{~d}$

$95.33 \mathrm{a}$

$93.16 \mathrm{~b}$

$\begin{array}{lll}25.00 & 24.33 & 25.83 \mathrm{a} \\ 23.00 & 22.66 & 23.83 \mathrm{~b} \\ 21.66 & 21.33 & 22.16 \mathrm{c} \\ 20.66 & 19.66 & 20.83 \mathrm{~d} \\ 22.58 & 22.00 & \end{array}$

which reduced seed weight. Results supporting our findings were also quoted by Alam et al. (2012) and Hussain et al. (2013), who also suggested a significant performance of different transplantation date on 1000-grain weight $(\mathrm{g})$ in rice.

Analysis of variance indicated seedling hill-1, transplanting date and interaction showed significant results about biological yield Table 4. Whereas transplantation dates had a non-significant effect on biological yield $\left(\mathrm{kg} \mathrm{ha}^{-1}\right)$. Safdar et al. (2008) reported significant influence of transplanting time on biological yield of rice. Rasool et al. (2012) corroborated our findings by showing significant results for biological yield. The increase in biomass yield may probably due to adequate plant density and suitable weather conditions which increased crop biomass under present combination Kobata and Uemuki (2014) recorded maximum biological yield with three seedlings per hill. Seedling hill ${ }^{-1}$ Grain yield data show similarity as in biological yield Table 4. The earlier transplanted rice took more time for growth, captured maximum sun light and resultantly maximum accumulation and transfer of photosynthetic towards economic yield (Khakwani et al., 2006). Islam et al. (2008) also intimated significant differences of transplantation dates for grain yield. Our results got support from the pre- vious findings of Asbur (2013) who also elaborated that planting density in rice had positive influence on grain yield. Seedling hill ${ }^{-1}$, transplanting date and interaction showed significant results in Table 4 for harvest index. Similarly, Vimlesh (2007) also reported that earlier transplantation increased the harvest index in rice. Rahman et al. (2013) elaborated results identical to our findings. Similarly, Ghao et al. (2015) corroborated our findings and obtained highest harvest index for earlier transplanting, as harvest index is affected by the temperature provided to young seedlings.

Benefit cost ratio is the ratio of overall discounted net returns divided by the total cost (Table 5). The maximum the benefit cost ratio, the higher will be the profit. The value greater than one means more benefits and less expenditure. In present endeavor, the maximum net return of Rs.107449/- and benefit cost ratio (2.70) was obtained from rice transplanted on 18th of July along with 3 seedlings per hill followed by net return of Rs.96972/- and Benefit cost ratio (2.54) in treatment with three seedling transplanted on $25^{\text {th }}$ of July. However, lowest benefit cost ratio (1.51) and net amount of Rs.31149/- was received from rice transplanted on last date i.e., $8^{\text {th }}$ of August in combination with single plant seedling. 
Table 4: Response of Fine Rice (Oryza sativa L.) to various Planting Dates and Seedling Densities on economical yields.

\begin{tabular}{|c|c|c|c|c|c|c|}
\hline \multirow{7}{*}{$\begin{array}{l}\text { Biological yield } \\
\left(\mathrm{kg} \mathrm{ha}^{-1}\right)\end{array}$} & \multirow{2}{*}{$\begin{array}{l}\text { Transplanting } \\
\text { Dates }\end{array}$} & \multicolumn{4}{|c|}{ Seedling Densities } & \multirow[t]{2}{*}{ Mean } \\
\hline & & $\mathrm{P}_{1}$ & $\mathrm{P}_{2}$ & $\mathrm{P}_{3}$ & $\mathbf{P}_{4}$ & \\
\hline & $\mathrm{D}_{1}(18-07-2017)$ & $11000 \mathrm{a}-\mathrm{d}$ & $11692 \mathrm{a}$ & 11755 a & $11681 \mathrm{a}$ & $11532 \mathrm{a}$ \\
\hline & $\mathrm{D}_{2}(25-07-2017)$ & $10411 \mathrm{bcd}$ & $11104 \mathrm{a}-\mathrm{d}$ & $11318 \mathrm{ab}$ & $11441 \mathrm{ab}$ & $11068 \mathrm{~b}$ \\
\hline & $\mathrm{D}_{3}(01-08-2017)$ & 9925 de & $10671 \mathrm{a}-\mathrm{d}$ & $10807 \mathrm{a}-\mathrm{d}$ & 11059 a-d & 10615 c \\
\hline & $\mathrm{D}_{4}(08-08-2017)$ & 9200 e & 10212 cde & $10407 \mathrm{bcd}$ & $10796 a-d$ & $10154 \mathrm{~d}$ \\
\hline & Mean & $10134 \mathrm{a}$ & $10920 \mathrm{a}$ & $11072 \mathrm{a}$ & $11244 \mathrm{a}$ & \\
\hline \multirow{6}{*}{$\begin{array}{l}\text { Grain yield (kg } \\
\text { ha }^{-1} \text { ) }\end{array}$} & & & & & & \\
\hline & $\mathrm{D}_{1}(18-07-2017)$ & $3511 \mathrm{fg}$ & 4000 cde & $4700 \mathrm{a}$ & $4433 \mathrm{ab}$ & $4161 \mathrm{a}$ \\
\hline & $\mathrm{D}_{2}(25-07-2017)$ & $3033 \mathrm{hi}$ & 3759 ef & $4411 \mathrm{abc}$ & $4226 \mathrm{bcd}$ & $3857 \mathrm{~b}$ \\
\hline & $\mathrm{D}_{3}(01-08-2017)$ & $2822 \mathrm{ij}$ & $3515 \mathrm{fg}$ & 4104 bcd & 3967 de & 3602 c \\
\hline & $\mathrm{D}_{4}(08-08-2017)$ & $2540 \mathrm{j}$ & $3267 \mathrm{gh}$ & 3850 def & 3668 efg & $3331 \mathrm{~d}$ \\
\hline & Mean & 2977 c & $3635 \mathrm{~b}$ & $4266 \mathrm{a}$ & $4073 \mathrm{a}$ & \\
\hline \multirow{6}{*}{$\begin{array}{l}\text { Harvest index } \\
\text { (\%) }\end{array}$} & & & & & & \\
\hline & $\mathrm{D}_{1}(18-07-2017)$ & $32.15 \mathrm{dg}$ & 34.36 be & 39.99 a & $37.95 \mathrm{abc}$ & $36.11 \mathrm{a}$ \\
\hline & $\mathrm{D}_{2}(25-07-2017)$ & $29.35 \mathrm{efg}$ & $34.04 \mathrm{bf}$ & $38.95 \mathrm{ab}$ & $36.93 \mathrm{ad}$ & $34.82 \mathrm{~b}$ \\
\hline & $\mathrm{D}_{3}(01-08-2017)$ & $28.66 \mathrm{fg}$ & $33.09 \mathrm{cg}$ & $37.98 \mathrm{abc}$ & $35.89 \mathrm{ad}$ & $33.91 \mathrm{c}$ \\
\hline & $\mathrm{D}_{4}(08-08-2017)$ & $27.74 \mathrm{~g}$ & $32.21 \mathrm{dg}$ & $37.00 \mathrm{ad}$ & $33.97 \mathrm{bf}$ & $32.73 \mathrm{~d}$ \\
\hline & Mean & $29.48 \mathrm{~b}$ & $33.42 \mathrm{ab}$ & $38.48 \mathrm{a}$ & $36.19 \mathrm{a}$ & \\
\hline
\end{tabular}

Table 5: Benefit cost ratio/net return as received from combine use of seedling densities and transplanting time.

\begin{tabular}{|c|c|c|c|c|c|c|c|c|}
\hline Treatmen & & Grain yield & Cost $(1$ & Rs.) & & & Net Inc & e/Return \\
\hline $\begin{array}{l}\text { Seedling } \\
\text { densities }\end{array}$ & Transplanting Dates & & Fixed & Variable & & (Rs.) & $\begin{array}{l}\text { Tincon } \\
\text { BCR }\end{array}$ & $T$ cost \\
\hline $\mathrm{P}_{1}$ & $\mathrm{~T} \mathrm{D}_{1} 18^{\text {th }}$ July & 3511 & 50926 & 10000 & 60926 & 127273 & 66347 & 2.08 \\
\hline & $\mathrm{T} \mathrm{D}_{2} 25^{\text {th }}$ July & 3033 & 50926 & 10000 & 60926 & 109946 & 49020 & 1.80 \\
\hline & $\mathrm{T} \mathrm{D}_{3} 1^{\text {st }}$ August & 2822 & 50926 & 10000 & 60926 & 102297 & 41371 & 1.67 \\
\hline & $\mathrm{T} \mathrm{D}_{4} 8^{\text {th }}$ August & 2540 & 50926 & 10000 & 60926 & 92075 & 31149 & 1.51 \\
\hline $\mathrm{P}_{2}$ & $\mathrm{~T} \mathrm{D}_{1} 18^{\text {th }}$ July & 4000 & 50926 & 11000 & 61926 & 145000 & 83074 & 2.34 \\
\hline & $\mathrm{T} \mathrm{D}_{2} 25^{\text {th }}$ July & 3759 & 50926 & 11000 & 61926 & 136263 & 74337 & 2.20 \\
\hline & $\mathrm{T} \mathrm{D}_{3} 1^{\text {st }}$ August & 3515 & 50926 & 11000 & 61926 & 127418 & 65492 & 2.05 \\
\hline & $\mathrm{T} \mathrm{D}_{4} 8^{\text {th }}$ August & 3267 & 50926 & 11000 & 61926 & 118428 & 56502 & 1.91 \\
\hline $\mathrm{P}_{3}$ & $\mathrm{~T} \mathrm{D}_{1} 18^{\text {th }}$ July & 4700 & 50926 & 12000 & 62926 & 170375 & 107449 & 2.70 \\
\hline & $\mathrm{T} \mathrm{D}_{2} 25^{\text {th }}$ July & 4411 & 50926 & 12000 & 62926 & 159898 & 96972 & 2.54 \\
\hline & $\mathrm{T} \mathrm{D}_{3} 1^{\text {st }}$ August & 4104 & 50926 & 12000 & 62926 & 148770 & 85844 & 2.36 \\
\hline & $\mathrm{T} \mathrm{D}_{4} 8^{\text {th }}$ August & 3850 & 50926 & 12000 & 62926 & 139562 & 76636 & 2.21 \\
\hline $\mathrm{P}_{4}$ & $\mathrm{~T} \mathrm{D}_{1} 18^{\text {th }}$ July & 4433 & 50926 & 13000 & 63926 & 160696 & 96770 & 2.51 \\
\hline & $\mathrm{T} \mathrm{D}_{2} 25^{\text {th }}$ July & 4226 & 50926 & 13000 & 63926 & 153192 & 89266 & 2.39 \\
\hline & $\mathrm{T} \mathrm{D}_{3} 1^{\text {st }}$ August & 3967 & 50926 & 13000 & 63926 & 143803 & 79877 & 2.24 \\
\hline & $\mathrm{T} \mathrm{D}_{4} 8^{\text {th }}$ August & 3668 & 50926 & 13000 & 63926 & 132965 & 69039 & 2.07 \\
\hline
\end{tabular}

Sale price of paddy $=36.25 / \mathrm{kg}$, Purchase cost of Urea $=$ Rs.1300/bag, Purchase cost of $S S P=R s .900 / \mathrm{bag}$, Purchase cost of $S O P=$ Rs. 5000/bag, Cost of hebicide $($ Rifit $)=$ Rs.500/ $400 \mathrm{ml}$ bottle, Cost of Insecticide $($ Vertaco $)=$ Rs.1100/4kg bag 
The results indicated that maximum grain yield (4700 $\mathrm{kg} \mathrm{ha}{ }^{-1}$ ) was obtained from 3 seedlings hill ${ }^{-1}$ transplanted on $18^{\text {th }}$ of July. Therefore, it is recommended that for obtaining highest grain yield and maximum net profit, fine rice variety Super Basmati should be transplanted on mid of July along with three seedlings hill ${ }^{-1}$ under agro ecological conditions of Dera Ismail Khan.

\section{Novelty Statement}

Pakistan lying in that geographic area which is pound to climate change scenario and this climate change causes reduction in vegetative $\&$ economical yield of our summer crops like rice. Considering the importance of plant population with different planting dates in reclaiming the climate change in physiology of rice the present research is designed accordingly. From this research it is established that fine rice can be successfully produced in arid climates with reasonable quality and economic return if planted on proper time and density.

\section{Author's Contribution}

M. Azam: Research Scholar.

Iqtidar Hussain: Research idea, research management and corresponding author.

Ghazanfar ullah: Supervised the article.

A.A. Khakwani: $\mathrm{Co}$-Supervisor.

M.S. Baloch: Chairperson of department of Agronomy.

K. Waseem and M. Amjed Nadeem: Collected data, data entry in SPSS and analysis.

M.K. Javaid: Helped in management of field.

\section{Conflict of interest}

The authors have declared no conflict of interest.

\section{References}

Ahmad, S., Hussain, A., Ali, H. and Ashfaq, A. 2005. Transplanted fine rice (Oryza sativa L.) productivity as affected by plant density and irrigation regimes. Int. J. Agric. Biol. 7(3): 445447.

Alam, F. 2006. Effect of spacing, number of seedlings hill $^{-1}$ and fertilizer management on the performance of Boro rice cv. BRRI dhan
Alam, M.S., Baki, M.A., Sultana, M.S., Ali, K.J. and Islam, M.S. 2012. Effect of variety, spacing and number of seedlings per hill on the yield potentials of transplant aman rice. Int. J. Agric. Agric. Res. 2: 10-15.

Amin, M., Khan, M.A., Khan, E.A. and Ramzan, M. 2004. Effect of increased plant density and fertilizer dose on the yield of rice variety IR-6. J. Res. Sci. 15(1): 9-16.

Asad, A.A.K., Inamullah, F.A.S., Naeem, L.Z.M. and Khan, M.N. 2015. Phenological traits of rice as influenced by seedling age and number of seedling per hill under temperate region. J. Biol. Agric. Healthcare. 5: 145-49.

Asbur, Y. 2013. Effect of seedling number per hill and seedling age on plant growth and grain yield Ciherang Rice. In Proceedings of the Annual International Conference, Syiah Kuala University-Life Sciences \& Engineering Chapter (Vol. 3, No. 3).

Baloch, A.W., Soomro, A.M., Javed, M.A., Ahmed, M., Bughio, H.R., Bughio, M.S. and Mastoi, N.N. 2012. Optimum plant density for high yield in rice (Oryza sativa L.). Asian J. Plant Sci. 1(1): 25-27.

Baloch, M.S., Awan, I.U. and Hassan, G. 2006. Growth and yield of rice as affected by transplanting dates and seedlings per hill under high temperature of Dera Ismail Khan, Pakistan. J. Zhejiang University Sci. B. 7(7): 572-579. https://doi.org/10.1631/jzus.2006. B0572

Bhowmik, S.K., Sarkar, M.A.R. and Zaman, F. 2012. Effect of spacing and number of seedlings per hill on the performance of aus rice cv. NERICA 1 under dry direct seeded rice (DDSR) system of cultivation. J.of Bangladesh Agric. Uni. 10(2): 191-195. https://doi. org/10.3329/jbau.v10i2.14681

Biswas, K.K., Hussain, I., Abuyusuf, A.S.M., Hassan, M.D.Z. and Jannat, N.A. 2015. Hill spacing and number of seedlings per hill on the yield of T. Aman rice (var. BRRI dhan52) in the tidal ecosystem. Am. Res. Thoughts. 1(11): 2392-876.

Bozorgi, H.R., Faraji, A., Danesh, R.K., Keshavarz, A., Azarpour, E. and Tarighi, F. 2011. Effect of plant density on yield and yield components of rice. World Appl. Sci. J. 12(11): 2053-2057. 
Chauhan, B.S. 2012. Weed ecology and weed management strategies for dry-seeded rice in Asia. Weed Technol. 26(1): 1-13. https://doi. org/10.1614/WT-D-11-00105.1

Chutia, J. and Borah, S.P. 2012. Water stress effects on leaf growth and chlorophyll content but not the grain yield in traditional rice (Oryza sativa Linn.) genotypes of Assam, India II. Protein and proline status in seedlings under PEG induced water stress. Am. J. Plant Sci. 3(07): 971. https://doi.org/10.4236/ajps.2012.37115

FAOSTAT. 2017. Available online: http://www. fao.org/faostat/en/\#data. QC (accessed on $2^{\text {nd }}$ August 2017).

Faruk, M.O., Rahman, M.A. and Hassan, M.A. 2009. Effect of seedling age and number of seedling per hill on the yield and yield contributing characters of BrriDhan 33. Int. J. Sustain. Crop Prod. 4(1): 58-61.

Ghao, Y., Lu, H., Yang, S. and Wang, Y. 2015. Impacts of biochar addition on rice yield and soil properties in a cold waterlogged paddy for two crop seasons. Field Crops Res. 191: 161167. https://doi.org/10.1016/j.fcr.2016.03.003

Gill, M.S., Gill, J.S. and Gill, G.K. 2009. Effect of time of transplanting on performance of different Basmati rice (Oryza sativa L.) cultivars. Environ. Ecol. 27(4A): 1757-1759.

Hasanuzzaman, M., Nahar, K., Roy, T.S., Rahman, M.L., Hossain, M.Z. and Ahmed, J.U. 2009. Tiller dynamics and dry matter production of transplanted rice as affected by plant spacing and number of seedling per hill. Acad. J. Plant Sci. 2(3): 162-168.

Hussain, A.S.M.I., Hoque, M.M., Huda, M.N., Hossain, D. and Shahjahan, M. 2013. Effect of planting time and nitrogen application on the yield and seed quality of T. Aman rice (Oryza sativa L.). Bangladesh J. Agric. Res. 38(4): 673688. https://doi.org/10.3329/bjar.v38i4.19660

Imran, A.A.K., Inamullah, F.A.S., Naeem, L.Z.M. and Khan, M.N. 2015. Phenological traits of rice as influenced by seedling age and number of seedling per hill under temperate region. J. Biol. Agric. Healthcare. 5: 145-49.

Islam, M.S., Hossain, M.A., Chowdhury, M.A.H. and Hannan, M.A. 2008. Effect of nitrogen and transplanting date on yield and yield components of aromatic rice. J. Bangladesh Agric. Uni. 6(2): 291-296. https://doi.org/10.3329/jbau. v6i2.4824
Islam, M.S., Sarkar, M.A.R., Alam.M.J. Kashem M.A., Rafii M.Y. and Latif M.A. 2014. Effect of number of seedling hill ${ }^{-1}$ on the growth and yield of Aromatic fine rice varieties in rain fed condition. Life Sci. J. 11(8).

Khakwani, A.A., Zubair, M., Mansoor, M., Naveed, K., Shah, I.H., Wahab, A. and Ahmed, I. 2006. Agronomic and morphological parameters of rice crop as affected by date of transplanting. J. Agron. 5(2): 248-250. https://doi.org/10.3923/ ja.2006.248.250

Khalifa, A.A.B.A. 2009. Physiological evaluation of some hybrid rice varieties under different sowing dates. Aust. J. Crop Sci. 3(3): 178-183.

Kobata,T. and Uemuki, N.2014. High temperatures during the grain-filling period do not reduce the potential grain dry matter increase of rice. Agron. J. 96(2): 406-414. https://doi. org/10.2134/agronj2004.0406

Kostylev, P.I. and Popov, S.S. 2016. The number of grains in a rice panicle as a selection criterion on productivity. An Agrarian Science of EuroNorth-East.

Lin, X.Q., Zhu, D.F., Chen, H.Z. and Zhang, Y.P. 2009. Effects of plant density and nitrogen application rate on grain yield and nitrogen uptake of super hybrid rice. Rice Sci. 16(2): 138-142. $\quad$ https://doi.org/10.1016/S16726308(08)60070-0

Mulcahy, D.N., Mulcahy, D.L. and Dietz, D. 2013. Biochar soil amendment increases tomato seedling resistance to drought in sandy soils. J. Arid Environ. 88: 222-225. https://doi. org/10.1016/j.jaridenv.2012.07.012

Nangyal, H., Shah, A.H. and Akhtar, N. 2016. Effect of different transplanting dates on germplasm rice yield and its yield components. Am.-Eur. J. Agric. Environ. Sci. 16(3): 571-576.

Noreen, R., Khan, S.U., Rabbani, A., Kanwal, A. and uzair, B. 2020. Screening of different rice (Oryza sativa L.) varieties for genetic diversity and bacterial blight resistance gene. Pak. J. Bot. 52(3): 1087-1096. https://doi.org/10.30848/ PJB2020-3(41)

Obulamma, U., Reddeppa, R. and Reddy, R. 2002. Effect of spacing and seedling number on growth and yield of hybrid rice. J. Res. Archarya. 30(1): 76-78.

Rahman, K.S., Paul, S.K., Sarkar, M.A.R. and Islam, M.S. 2013. Growth parameters of transplant aman rice (cv. BRRIdhan 52) as influenced by 
age of tiller seedlings, number of tiller seedlings hill $^{-1}$ and level of USG. J. Environ. Sci. Nat. Resour. 6(2): 101-108.https://doi.org/10.3329/ jesnr.v6i2.22104

Rasool, F., Habib, R. and Bhat, M.I. 2012. Evaluation of plant spacing and seedlings per hill on rice (Oryza sativa L.) productivity under temperate conditions in Pakistan. J. Agric. Sci. 49(2): 169-172.

Safdar, M.E., Ali, A., Muhammad, S., Sarwar, G. and Awan, T.H. 2008. Effect of transplanting dates on paddy yield of fine grain rice genotypes. Pak. J. Bot. 40(6): 2403-2411.

Sharma, A., Dhaliwal, L.K., Sandhu, S.K. and Singh, S. 2011. Effect of plant spacing and transplanting time on phenology, tiller production and yield of rice (Oryza sativa L.). Int. J. Agric. Sci. 7: 249-253.

Shrirame, M.D., Rajgire, H.J. and Rajgire, A.H. 2000. Effect of spacing and seedling number per hill on growth attributes and yield of rice hybrids under lowland condition. J. Soils Crops. 10(1). 109-113.

Singh., S.R.K., Kumar, A.R.,Joseph, M., Singh, V.P., Singh, A.K. and Mohapara, T. 2008. Integrating marker assisted background analysis with foreground selection for identification of superior bacterial blight resisted recombinants in Basmati rice. Plant Breed. 127(2): 131$139 . \quad$ https://doi.org/10.1111/j.14390523.2007.01458.x

Steel, R.G.D., Torrie, J.H. and Dicky, D.A. 1997.
Principles and procedures of statistics, A biometrical approach. $3^{\text {rd }}$ Ed. McGraw Hill, Inc. Book Co. N.Y. (USA) pp. 352-358.

Turin, MST, S., Arifuzaman, MD. and Azad, M.A.K. 2021. Screening of rice Germplasm for drought stress tolerance using multivariate analysis. Pak. J. Bot. 53(2): 393-400. https://doi. org/10.30848/PJB2021-2(7)

Vijayalaxmi, G., Sreenivas, G. and Rani, P.L. 2016. Evaluation of CERES-rice model under various plant densities and age of seedlings in transplanted rice of Southern Telangana zone of Telangana State, India. Int. J. Curr. Microbiol. Appl. Sci. 5(4): 667-674. https:// doi.org/10.20546/ijcmas.2016.504.076

Vimlesh, Y. 2007. Studies on the effect of dates of planting, plant geometry and number of seedlings per hill in hybrid rice (Oryza sativa L.) (Doctoral Dissertation, CSA University of Agriculture and Technology; Kanpur).

Wang, S., Wu, K., Yuan, Q. Liu, X., Liu, Z., Lin, X. and Zhang, G. 2012. Control of grain size, shape and quality by OsSPL16 in rice. Nat. Gen. 44(8): 950. https://doi.org/10.1038/ ng. 2327

Zhaofen,Y., syed, T.A.U.K., Qiang, C., Zhenzhou, L., Weixing., Yan, Z. and Xiaojun L. 2016. Indicators For diagnosing nitrogen status of rice based on Chlorophyll meter readings. Int. J. Field crops Res. 185: 12-20. https://doi. org/10.1016/j.fcr.2015.10.003 